\title{
Comment on: Gleicher N et al., 2016. Reprod biol endocrinol Sep 5;14(1)
}

\author{
Ashley W. Tiegs ${ }^{1 *}$, James A. Grifo², Santiago Munné3 ${ }^{3}$ David H. McCulloh ${ }^{1}$ and Brooke Hodes-Wertz ${ }^{2}$
}

Keywords: Mosaicism rate, Blastocyst, Euploid, Misdiagnosis

To the Editors,

We read with interest the recent manuscript of Gleicher, et al. regarding their statement that we described a mosaicism rate of $40 \%$; it is presumed that this conclusion was derived from our report that two of five miscarried embryos (of 525 diagnosed euploid single thawed embryo transfers) were misdiagnosed, which was identified upon reanalysis of biopsied specimens [1]. Our manuscript did not intend (nor was it designed) to assess the mosaicism rate of blastocysts diagnosed by aCGH of trophectoderm biopsies.

Data shows that infants born from in vitro fertilization have low mosaicism rates. NGS-diagnosed euploid trophectoderm samples have been reanalyzed in at least 124 embryos showing $100 \%$ euploidy concordance [2-4]. Gleicher, et al. excluded our 280 normal deliveries from the denominator in their extrapolation of our data secondary to the possibility that these infants were derived from mosaic embryos [1]. This exclusion is misleading. To assume that $40 \%$ of the infants delivered were derived from self-corrected mosaic embryos is equally misleading.

Our data never intended to evaluate mosaicism rates in embryos, and citing our data in such a way misrepresents our findings. We suggest that instead, the authors should perform experiments to determine the rate of mosaicism experimentally. This should potentially include repeat biopsy of embryos at multiple sites, including the inner cell mass, and subsequently analyzing biopsied specimens using a systemic, validated assay. We are aware of several manuscripts in various stages of the peer review process that actually address this specific question and report rates

\footnotetext{
* Correspondence: Ashley.Wood@nyumc.org

${ }^{1}$ Department of Obstetrics and Gynecology, New York University School of Medicine, 550 First Avenue, NBV 9E2, New York 10016, NY, USA

Full list of author information is available at the end of the article
}

much lower than the rates that the authors inaccurately extrapolate from our data.

\author{
Acknowledgements \\ Not applicable. \\ Funding \\ None. \\ Availability of data and materials \\ Not applicable.

\section{Authors' contributions} \\ AT, JG and SM were all major contributors in crafting the above \\ commentary. DH and BW were major contributors in editing the above \\ commentary. All authors read and approved the final manuscript.
}

\section{Competing interests}

The authors declare the following competing interests: Santiago Munne, PhD: CSO for CooperGenomics.

\section{Consent for publication \\ Not applicable.}

Ethics approval and consent to participate Not applicable.

\section{Publisher's Note}

Springer Nature remains neutral with regard to jurisdictional claims in published maps and institutional affiliations.

\section{Author details}

1Department of Obstetrics and Gynecology, New York University School of Medicine, 550 First Avenue, NBV 9E2, New York 10016, NY, USA. ${ }^{2}$ New York University Fertility Center, New York University School of Medicine, 660 First Avenue, 5th floor, New York 10016, NY, USA. ${ }^{3}$ Reprogenetics, New York, USA.

Received: 17 March 2017 Accepted: 17 March 2017

Published online: 05 April 2017

\section{References}

1. Gleicher N, Vidali A, Braverman J, Kushnir VA, Barad DH, Hudson C, Wu YG, Wang Q, Zhang L, Albertini DF, International PGS Consortium Study Group. Accuracy of preimplantation genetic screening (PGS) is compromised by degree of mosaicism of human embryos. Reprod Biol Endocrinol. 2016;14(1):54.

2. Kung A, Munné S, Bankowski B, Coates A, Wells D. Validation of nextgeneration sequencing for comprehensive chromosome screening of embryos. Reprod Biomed Online. 2015;31:760-9. 
3. Fiorentino F, Biricik A, Bono S, Spizzichino L, Cotroneo E, Cottone G, Kokocinski F, Michel CE. Development and validation of a next-generation sequencing - based protocol for 24-chromosome aneuploidy screening of embryos. Fertil Steril. 2014; 101:1375-82.

4. Wells D, Kaur K, Rico A, Grifo J, Anderson S, Sherlock J, Taylor JC, Munné S. Clinical utilization of a rapid low-pass whole-genome sequencing technique for the diagnosis of aneuploidy in human embryos prior to implantation. J Med Genet. 2014;51:553-62.

Submit your next manuscript to BioMed Central and we will help you at every step:

- We accept pre-submission inquiries

- Our selector tool helps you to find the most relevant journal

- We provide round the clock customer support

- Convenient online submission

- Thorough peer review

- Inclusion in PubMed and all major indexing services

- Maximum visibility for your research

Submit your manuscript at www.biomedcentral.com/submit 